\title{
Regional and Seasonal Differences in Species Composition and Trophic Groups for Tidepool Fishes of a Western Pacific Island - Taiwan
}

\author{
Colin K. C. Wen ${ }^{1 *}$, Li-Shu Chen ${ }^{2}$ and Kwang-Tsao Shao ${ }^{3}$ \\ ${ }^{1}$ Department of Life Science, Tunghai University \\ 1727 Taiwan Boulevard Section 4, Xitun District, Taichung 40704, Taiwan \\ 2 National Museum of Marine Science and Technology \\ 367 Pei-Ning Road, Zhongzheng District, Keelung 202, Taiwan \\ ${ }^{3}$ Biodiversity Research Center, Academia Sinica, Taipei 115, Taiwan \\ Email: Ischen@mail.nmmst.gov.tw
}

\begin{abstract}
Spatial and temporal variations in the species composition of assemblages are common in many marine organisms, including fishes. Variations in the fish species composition of subtidal coral reefs have been well documented, however much less is known about such differences for intertidal fish assemblages. This is surprising, given that intertidal fishes are more vulnerable to terrestrial human disturbances. It is critical to evaluate the ecology and biology of intertidal fishes before they are severely impacted by coastal development, especially in developing countries such as those in the tropical western Pacific region where coastal development is rapidly increasing. In this study, we investigated the species composition, abundance, biomass and species number (richness) for intertidal fish assemblages in subtropical (northern) and tropical (southern) Taiwan across four seasons by collecting fishes from tidepools using clove oil. We also examined the gut contents of collected fishes to identify their trophic functional groups in order to investigate regional and seasonal variations for different trophic groups. We found significant differences in the species composition of tidepool fish assemblages between subtropical and tropical Taiwan. Bathygobius fuscus, Abudefduf vaigiensis and Istiblennius dussumieri were dominant species in subtropical Taiwan, whereas Bathygobius coalitus, Abudefduf septemfasciatus and Istiblennius lineatus were dominant in tropical Taiwan. Other species such as Bathygobius cocosensis, Abudefduf sordidus and Istiblennius edentulus were common in both regions. For trophic groups, omnivores and detritivores had or showed trends towards higher species numbers and abundances in the subtropical region, whereas herbivores, planktivores and general carnivores had or showed trends towards higher species numbers and biomass in the tropical region. Overall, many intertidal fish species and trophic groups showed differences in abundance, biomass and species number between subtropical and tropical Taiwan. Further studies on large scale geographical gradients in trophic groups and species compositions in the Indo-west Pacific region are encouraged to assist with ecosystem monitoring and assessment.
\end{abstract}

Keywords: Intertidal fishes, spatio-temporal pattern, feeding guild, diet

\section{Introduction}

Both terrestrial and marine organisms often display spatial and temporal patterns in abundance and diversity, which are strongly related to environmental variations. For example, a warmer climate and a higher variety of habitats and prey types in the tropics result in higher abundances or diversity of animals and plants at the equator with a steady decline towards the poles (reviews in Hillebrand, 2004a). Compared to terrestrial ecosystems, marine ecosystems tend to show much clearer spatial and temporal patterns in abundance and diversity due to a more consistent gradient of environmental factors (Hillebrand, 2004b; Dawson and Hamner, 2008). In marine environments, reef- associated organisms show a strong correlation between space/seasons and abundance/diversity (Mora et al., 2003; Bellwood et al., 2005). The species compositions of fish assemblages in particular have been found to show clear spatial and temporal patterns which are linked to fish migratory and reproductive behavior (Hyndes et al., 1999; Jaureguizar et al., 2004). Other factors can also explain spatial and temporal patterns of reef organisms, including higher food or habitat availability in the warmer climate closer to the equator (Bellwood and Hughes, 2001), higher productivity and energy in the tropics (Gaston, 2000) and more suitable temperature ranges in the tropics (Harriott and Banks, 2002; Munday, 2002). While fishes of reef ecosystems are well-studied, spatial 
and temporal patterns in species abundances and diversity for other marine ecosystems are not so clear (but see Ysebaert and Herman, 2002; Zabin et al., 2013; Arakaki et al., 2014; Okada et al., 2015).

Geographical or latitudinal patterns are also observed in the abundance and diversity of many trophic groups, such as herbivores, omnivores and carnivores (Hillebrand, 2004a). These trophic groups generally increase in abundance and diversity with proximity to the equator, and such geographical trends might be due to the availability of their food sources (Carnicer and Díaz-Delgado, 2008). The abundance and diversity of many different herbivores for example, has been shown to be determined by the geographical distribution of the algae or plants they consume (Floeter et al., 2005; Novotny et al., 2006; Kissling et al., 2007). Although the food sources of omnivores and carnivores are abundant closer to the equator, many studies suggest that diverse habitats and the environmental conditions are what drive high omnivore and carnivore diversity in the tropics (Worm et al., 2005; Bojarska and Selva, 2012; Díaz-Ruiz et al., 2013). However, most broad geographical patterns in the abundance and diversity of trophic groups have been examined through meta-analyses conducted on large studies of species composition and diet (González-Bergonzoni et al., 2012). The limited information available on trophic structures in the marine environment makes it difficult to examine geographical patterns of abundance and diversity for each trophic group in marine ecosystems. In addition, seasonal variation in food sources also affects the diet of predators which can complicate investigations of geographical patterns in trophic groups (Afeworki et al., 2013). Comprehensive studies on the diet of organisms and species compositions in marine ecosystems across seasons and regions are necessary in order to understand how space and time interact to influence patterns of abundance and diversity for marine trophic groups. This is particularly so for marine ecosystems other than reefs, such as intertidal zones which have received relatively little attention (Wen et al., 2005; Pennings et al., 2009; Feller et al., 2013).

Intertidal zones are defined as areas between the high tide line and the low tide line. This may include different habitats such as salt marsh, mangrove, sandy beach and rocky/reef tidepool (Horn et al., 1999). These areas are subjected to large daily fluctuations in many environmental parameters (e.g. temperature and salinity) due to the change of water level with the tides (Underwood and Chapman, 2000). Marine organisms, including vertebrates (i.e. fish), living in intertidal zones have adapted to this harsh environment (Gibson and Yoshiyama, 1999; Plaut, 1999). Intertidal fishes have physiological adaptations that allow them to cope with a harsh daily environment, and consequently they tend to be more resistant to acute environmental damage or pollution than other fishes (Ellis and Bell, 2013). Despite this, species within these intertidal marine ecosystems are vulnerable to human disturbance, especially on the coasts of many developing countries in the tropical Pacific region (Horn et al., 1999; Wen et al., 2010; Gillet, 2011). Intertidal areas have been heavily impacted by human activities, particularly urbanization and development in coastal areas (Kennish, 2001; Bulleri, 2005). In addition, artificial structures have extended into natural coastal habitats (Bulleri and Chapman, 2010), affecting many marine organisms and greatly altering the ecosystems (Burt et al., 2009; Wen et al., 2010). Currently, a limited understanding of intertidal species composition in some areas, such as Taiwan, makes it impossible to examine broad differences in abundance and diversity in the tropical western Pacific region and how these may change over time with increasing human disturbances (Prochazka et al., 1999).

The island of Taiwan is located at the northern point of a marine biodiversity hotspot in the western Pacific Ocean (Chen and Shashank, 2009) and is divided into tropical and subtropical climatic regions (south and north). Subtidal reefs in northern and southern Taiwan have distinctly different species compositions (Shao et al., 2002; Hsiao et al., 2011), and these differences extend beyond Taiwan to other nearby countries (i.e. Japan and the Philippines, Liu et al., 2008; Chen and Shashank, 2009). The subtidal fish, coral and algal assemblages in Taiwan exhibit seasonal/temporal patterns due to the climatic and oceanic conditions they experience (Kuo et al., 2001; Tsai et al., 2004; Kuo et al., 2012). Whether the species composition and trophic groups of intertidal fish assemblages in northern and southern Taiwan show the same spatial and seasonal patterns as subtidal fish assemblages is yet to be determined. Species composition studies of intertidal fishes around the western Pacific Ocean have been conducted in Japan (Arakaki and Tokeshi, 2006; Murase, 2013, 2015) and Korea (Kwun et al., 2016). While some studies in Taiwan have provided a list of intertidal fish species (Lee, 1980), these studies lack quantified abundance data and information about fish diets. Quantified data on the number of individuals and species of tidepool fishes in Taiwan is critical in order to establish a baseline for evaluating the impact of human disturbances in the near future. Therefore, this study aims to establish spatial and temporal patterns in species composition and trophic groups for intertidal fish assemblages in Taiwan, and to compare these with surrounding regions in the western Pacfic Ocean. 


\section{Materials and Methods}

\section{Sampling sites and fish collection}

From 2001 to 2002, intertidal fishes were collected from three sites in northern Taiwan and three sites in southern Taiwan, to represent subtropical and tropical regions respectively based on their temperature records (additional Figure 1.). The intertidal zones between these two regions along the Taiwanese coast were sandy beach (western) or coastal cliff (eastern), where tidepools were not available to examine intertidal fishes. Tidepools with similar topography and environmental conditions were only found in Badouzih, Yeliou and Aodi of northern Taiwan, and Checheng, Siangjiaowan and Jioupeng of southern Taiwan (Figure 1..). Tidepools from northern Taiwan were limestone rocky tidepools with smooth surfaces and those from southern Taiwan were coral reef tidepools with rough surfaces and higher rugosity. We carefully choose tidepools with similar diameter and depth (approximately $2 \mathrm{~m}^{3}$ ) and elevation (midtide zone and 2-3 $m$ above waterline during low tide) to reduce possible confounding factors on fish composition (Cox et al., 2011). However, only one tidepool at each site was examined due to rare replicates being found at these sites.

In order to accommodate limited replication, which is common in the natural environment
(Legendre et al., 2010), we planned repeated sampling instead of pseudoreplication and rather than having no replication at all (Davies and Gray, 2015). As such, we sampled the same sites five times, three months apart so as to encompass all seasons, except in Siangjiaowan (where sampling was done four times). We sampled in January, April, August and October of 2001, and January of 2002. Sampling was conducted between 1100 and 1600 hours during low tide to help ensure stomach fullness of the collected fishes (Munoz and Ojeda, 1997). Fishes from tidepools were used to represent resident intertidal fishes, because daily migratory intertidal fishes would rarely stay within tidepools during low tide (Griffiths, 2003; Arakaki and Tokeshi, 2006). Clove oil and hand nets were used to collect tidepool fishes following Wen et al. (2005). We used clove oil (anaesthesia) rather than rotenone (fish poison) to collect tidepool fishes, because clove oil is just as effective for catching hardy intertidal fishes but is less damaging to the surrounding environment (Wen et al., 2005). In addition, most cryptic fishes (such as hole dwellers like Blenniidae) tend to vacate their holes or crevices before becoming paralyzed when clove oil is used, making collection easier. After being euthanized with clove oil, all collected fishes were injected with $10 \%$ seawater buffered formalin then transported to the laboratory in an icebox for identification and processing (Chen and Shao, 2010; Shao, 2017).

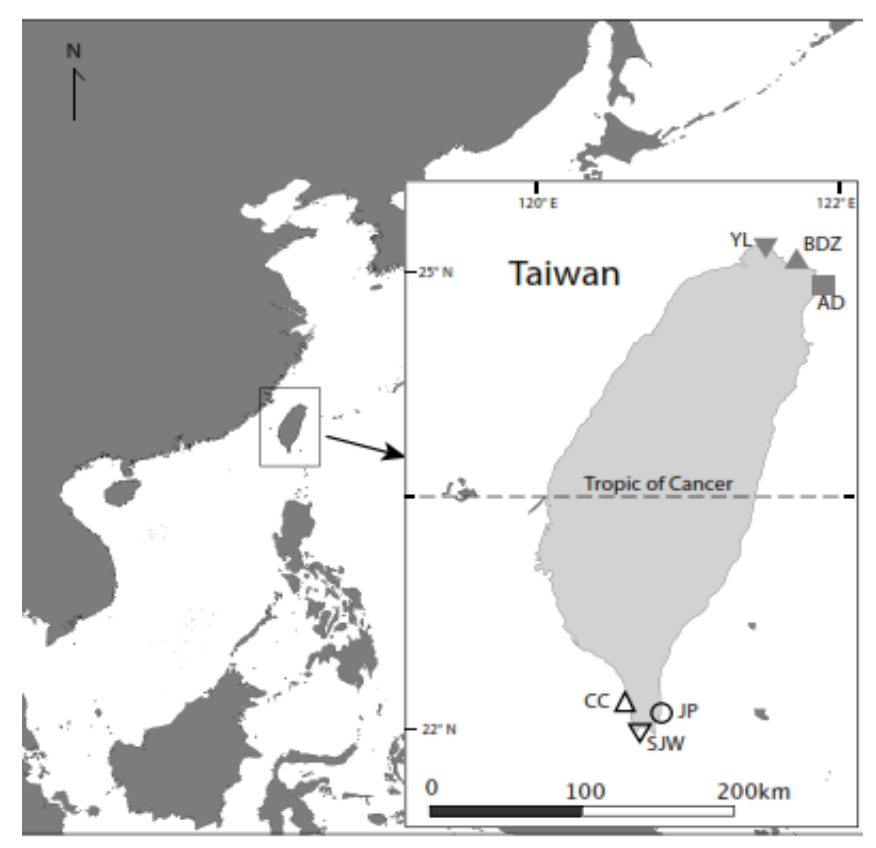

Figure 1. Map of Taiwan showing the locations of the six study sites. The three northern sites are Badouzih (BDZ,

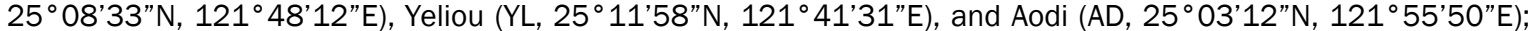
and the three southern sites are Checheng (CC, $\left.22^{\circ} 05^{\prime} 59^{\prime \prime} \mathrm{N}, 120^{\circ} 43^{\prime} 00^{\prime \prime} \mathrm{E}\right)$, Siangjiaowan (SJW, $21^{\circ} 55^{\prime} 28^{\prime \prime} \mathrm{N}$, $\left.120^{\circ} 49^{\prime} 58^{\prime \prime} \mathrm{E}\right)$, and Jioupeng (JP, $\left.22^{\circ} 08^{\prime} 25^{\prime \prime} \mathrm{N}, 120^{\circ} 53^{\prime} 40^{\prime \prime} \mathrm{E}\right)$. 


\section{Gut contents analysis}

The total length and wet body-weight of each collected individual were measured to the nearest millimetre and milligram respectively. The gut contents from each individual was removed and stored in a $10 \%$ seawater buffered formalin solution to preserve the food items. Food items from the gut contents were identified visually using a dissecting microscope (10X) and an optical microscope (50X) when food items were small (i.e. filamentous algae and detritus). Taxonomic identifications of prey were made using two standard field guides (Gosliner et al., 1996; Allen et al., 2003). The proportion of each food item in the gut contents was estimated using the point-contact method (Jones, 1968; German and Horn, 2006), because the major trophic group in this study was herbivores. This method approximated the volume or coverage of each item in the gut contents using a $10 \times 10$ net reticle with $0.5 \mathrm{~cm} \times 0.5 \mathrm{~cm}$ cells. The number of intersections on the reticle occupied by a gut item compared to all gut items represented its percentage in the individual fish. Although the volume, weight and frequency of food items in stomach contents analyses have commonly been evaluated using IRI (index of relative importance; Hyslop, 1980), this is not practical for fragmented and small food items commonly found in the gut contents of intertidal fishes (e.g. Blenniidae and Gobiidae). Food items were identified to the finest level possible, and then grouped at Class or Order level. The categories for gut contents were: Filamentous algae, Sheet algae, Corticated algae, Sand, Detritus, Foraminifera, Cyanobacteria, Gastropoda, Diatom, Medusa, Polychaeta, Insecta, Copepoda, Amphipoda, Isopoda, Ostracoda, Decapoda crab, Decapoda shrimp, Nauplius, Arthropoda, Heteropoda, Cirripedia, Bivalvia, Mysidae, Hydroida, Cladocera, Fish, Fish eggs, and Fish scales. Unidentifiable fragments of crustacean or other prey were defined as "unidentified crustacean" and "unidentified item" respectively.

\section{Trophic groups}

The dietary information collected for each species (Additional Table 1) was used to categorize all of the species into different trophic functional groups. These were: 1) herbivore, 2) detritivore, 3) planktivore, 4) omnivore, 5) general carnivore 6) benthic invertebrate feeder. In the scientific literature, no universal or concrete definition of trophic functional groups has been provided that incorporates the actual proportion of prey consumed by organisms (Gerking 1994). Herbivores and carnivores are generally thought of as solely consuming plant/algae and animals respectively (Horn and Ojeda, 1999; Norton and Cook, 1999). However, both herbivorous and carnivorous fishes can have other items in their stomachs that may not conform to such strict perceptions. Therefore, in this study, trophic functional groups were defined according to the predominant (>90\%) food category found in their gut contents. For example, herbivores were defined as organisms with $>90 \%$ algae in their gut contents, and carnivores defined as having $>90 \%$ animal prey. Fishes with both algae and animal prey in their gut but not more than $90 \%$ of any one category were defined as omnivores. At a finer scale, carnivores were divided into the further categories of: planktivore, benthic invertebrate feeder and general carnivore. Planktivores fed on predominantly (>90\%) zooplankton, benthic invertebrate feeders fed on $>90 \%$ small benthic invertebrates and amphipods ( $<5 \mathrm{~mm})$, and general carnivores on $>90 \%$ fish and large decapoda crustaceans ( $>5 \mathrm{~mm}$ ) such as shrimp and crabs. Although both biomass and abundance were chosen to examine trophic groups, biomass represents the trophic relationship better than abundance (Velasco et al., 2010). We differentiated between "resident" and "transient" species within functional groups, to distinguish between species occasionally trapped in tidepools or that occurred seasonally in a large group (transient), and those that stayed in the tidepools as permanent occupiers (resident). For example, Mugilidae and Atherinidae, which were categorised as transient fishes, were only caught once or twice throughout the whole study. Due to only a few transient species being collected on limited occasions, only resident trophic groups were compared between subtropical and tropical Taiwan. Resident and transient species were defined from both our own data and behavioral information from the literature (Horn et al., 1999; Griffiths, 2003; Arakaki and Tokeshi, 2006).

\section{Statistical analyses}

The number of individuals and the measured biomass for each tidepool were standardized according to the size of each tidepool prior to statistical analyses. The species richness of tidepool fishes was compared between subtropical and tropical Taiwan with rarefaction curves with repeated sampling (four seasons) sample-based Poisson model (Colwell et al., 2012). Rarefaction curves used an asymptote analysis based on Hill number and can estimate species diversity/richness from uneven sampling efforts and uneven sizes of sampling areas such as the uneven number of tidepool samples and tidepool sizes in this study (Work et al., 2010; Chao et al., 2014).

The influence of region, season and site (nested within region) on abundance, species number (richness) and biomass of total tidepool fishes and each trophic group were investigated 
Table 1. Full list of species collected and the number of individuals from each of the six study sites.

\begin{tabular}{|c|c|c|c|c|c|c|c|c|}
\hline Family & Species & Badouzih & Yeliou & Aodi & Checheng & Siangjiaowan & Jioupeng & Species total \\
\hline Pomacentridae & Abudefduf bengalensis & 3 & 0 & 2 & 0 & 0 & 0 & 5 \\
\hline Pomacentridae & Abudefduf notatus & 4 & 3 & 0 & 0 & 1 & 0 & 8 \\
\hline Pomacentridae & Abudefduf septemfasciatus & 0 & 0 & 1 & 2 & 11 & 17 & 31 \\
\hline Pomacentridae & Abudefduf sordidus & 36 & 32 & 9 & 20 & 7 & 14 & 118 \\
\hline Pomacentridae & Abudefduf vaigiensis & 55 & 90 & 7 & 4 & 20 & 0 & 176 \\
\hline Acanthuridae & Acanthurus triostegus & 0 & 0 & 0 & 2 & 6 & 4 & 12 \\
\hline Gobiidae & Asterropteryx semipunctata & 0 & 0 & 2 & 0 & 0 & 0 & 2 \\
\hline Gobiidae & Bathygobius coalitus & 1 & 0 & 1 & 8 & 10 & 80 & 100 \\
\hline Gobiidae & Bathygobius cocosensis & 23 & 10 & 31 & 7 & 10 & 18 & 99 \\
\hline Gobiidae & Bathygobius cotticeps & 8 & 0 & 2 & 0 & 7 & 0 & 17 \\
\hline Gobiidae & Bathygobius cyclopterus & 10 & 5 & 0 & 0 & 1 & 0 & 16 \\
\hline Gobiidae & Bathygobius fuscus & 49 & 27 & 68 & 0 & 0 & 0 & 144 \\
\hline Blenniidae & Blenniella bilitonensis & 2 & 0 & 10 & 0 & 0 & 0 & 12 \\
\hline Blenniidae & Blenniella chrysospilos & 0 & 0 & 11 & 0 & 0 & 0 & 11 \\
\hline Blenniidae & Blenniella periophthalmus & 0 & 1 & 1 & 2 & 0 & 0 & 4 \\
\hline Pomacentridae & Chrysiptera brownriggii & 0 & 0 & 0 & 1 & 0 & 0 & 1 \\
\hline Pomacentridae & Chrysiptera glauca & 0 & 0 & 2 & 1 & 9 & 8 & 20 \\
\hline Pomacentridae & Chrysiptera unimaculata & 0 & 0 & 0 & 6 & 17 & 1 & 24 \\
\hline Muraenidae & Echidna nebulosa & 0 & 0 & 0 & 0 & 16 & 0 & 16 \\
\hline Muraenidae & Echidna polyzona & 0 & 0 & 1 & 0 & 1 & 0 & 2 \\
\hline Tripterygiidae & Enneapterygius etheostomus & 11 & 1 & 4 & 0 & 0 & 0 & 16 \\
\hline Blenniidae & Entomacrodus decussatus & 3 & 0 & 0 & 0 & 0 & 2 & 5 \\
\hline Blenniidae & Entomacrodus striatus & 26 & 4 & 0 & 0 & 0 & 2 & 32 \\
\hline Serranidae & Epinephelus corallicola & 0 & 0 & 1 & 0 & 0 & 0 & 1 \\
\hline Kyphosidae & Girella mezina & 0 & 1 & 0 & 2 & 0 & 0 & 3 \\
\hline Serranidae & Grammistes sexlineatus & 0 & 0 & 0 & 3 & 1 & 0 & 4 \\
\hline Muraenidae & Gymnothorax favagineus & 0 & 0 & 1 & 0 & 1 & 0 & 2 \\
\hline Labridae & Halichoeres marginatus & 0 & 0 & 0 & 1 & 6 & 0 & 7 \\
\hline Atherinidae & Hypoatherina tsurugae & 0 & 0 & 0 & 0 & 653 & 0 & 653 \\
\hline Blenniidae & Istiblennius dussumieri & 7 & 10 & 96 & 0 & 4 & 0 & 117 \\
\hline Blenniidae & Istiblennius edentulus & 39 & 30 & 11 & 23 & 44 & 25 & 172 \\
\hline Blenniidae & Istiblennius lineatus & 5 & 1 & 49 & 24 & 18 & 27 & 124 \\
\hline Gobiidae & Istigobius ornatus & 0 & 0 & 0 & 0 & 12 & 0 & 12 \\
\hline Kuhliidae & Kuhlia mugil & 48 & 0 & 0 & 13 & 0 & 18 & 79 \\
\hline Mugilidae & Chelon macrolepis & 227 & 0 & 74 & 0 & 13 & 0 & 314 \\
\hline Lutjanidae & Lutjanus gibbus & 0 & 0 & 1 & 0 & 0 & 0 & 1 \\
\hline Kyphosidae & Microcanthus strigatus & 0 & 0 & 1 & 0 & 0 & 0 & 1 \\
\hline Blenniidae & Omobranchus germaini & 1 & 0 & 14 & 0 & 0 & 0 & 15 \\
\hline Apogonidae & Ostorhinchus cookii & 0 & 0 & 0 & 2 & 16 & 0 & 18 \\
\hline Gobiidae & Parioglossus formosus & 0 & 0 & 0 & 1 & 0 & 0 & 1 \\
\hline Blenniidae & Petroscirtes breviceps & 1 & 0 & 0 & 0 & 0 & 0 & 1 \\
\hline Blenniidae & Praealticus margaritarius & 1 & 1 & 0 & 0 & 0 & 4 & 6 \\
\hline Blenniidae & Praealticus striatus & 10 & 3 & 15 & 0 & 0 & 52 & 80 \\
\hline Blenniidae & Praealticus tanegasimae & 70 & 9 & 3 & 0 & 0 & 5 & 87 \\
\hline Gobiidae & Priolepis semidoliata & 0 & 0 & 1 & 0 & 0 & 0 & 1 \\
\hline Scorpaenidae & Scorpaenodes guamensis & 0 & 0 & 0 & 0 & 25 & 2 & 27 \\
\hline Clinidae & Springeratus xanthosoma & 1 & 0 & 0 & 0 & 0 & 0 & 1 \\
\hline Labridae & Stethojulis interrupta & 1 & 0 & 0 & 0 & 0 & 0 & 1 \\
\hline Labridae & Stethojulis terina & 0 & 0 & 1 & 0 & 0 & 0 & 1 \\
\hline Labridae & Stethojulis trilineata & 6 & 0 & 0 & 0 & 23 & 0 & 29 \\
\hline Terapontidae & Terapon jarbua & 1 & 0 & 0 & 0 & 0 & 0 & 1 \\
\hline Labridae & Thalassoma hardwicke & 0 & 0 & 0 & 1 & 1 & 1 & 3 \\
\hline Labridae & Thalassoma purpureum & 0 & 0 & 0 & 1 & 7 & 6 & 14 \\
\hline \multirow[t]{2}{*}{ Mugilidae } & Moolgarda cunnesius & 1 & 0 & 0 & 0 & 0 & 0 & 1 \\
\hline & Site total & 650 & 228 & 420 & 124 & 940 & 286 & 2648 \\
\hline
\end{tabular}


using Generalized Linear Mixed Models (GLMMs) and Generalized Linear Models (GLMs) as no prior assumption of homogeneity is required. A null model (no factor) and alternative models with a combination of two fixed factors (region and season) and a random factor (site nested within region) were compared with Akaike's information criterion (AIC; Symonds and Moussalli, 2011). AIC corrected (AICC) was used in this study due to the small sample size. The Akaike weights of each model were calculated from their AICC, and the model with the highest Akaike weight was selected as the best goodness-offit model to explain the effect of these three factors on tidepool fishes. The abundance, species number and biomass of each trophic group was analysed using a zero-inflated model with Poisson and negative binomial distribution due to many zeros in the data for a few trophic groups. Analyses were conducted in $\mathrm{R}$ with MASS, pscl, gImmADMB package (3.2.4; R Development Core Team, 2016) and also in PAST software (Hammer et al., 2001).

The species composition of intertidal fish assemblages was analysed using PERMANOVA (permutational multivariate analysis of variance). We examined differences in species composition between subtropical and tropical regions as well as among seasons (Anderson, 2001) using three factors: 1) region (subtropical vs. tropical), 2) site (nested within region), and 3 ) season. Homogeneity of the multivariate variance was verified for all three model terms using PERMDISP (permutational analysis of multivariate dispersions, Anderson, 2001). Conformation to normality is not required for this non-parametric multivariate analysis (Anderson and Millar, 2004).

The abundance data was log $(x+1)$ transformed and a similarity matrix was constructed using the modified Gower coefficient (Anderson et al., 2006). Type I (sequential) sums of squares was used to meet the assumptions of PERMANOVA due to the unbalanced sampling design. Monte Carlo randomization was used to generate a probability distribution for calculating a $p$ value $(p(M C))$ for each factor due to a limited sample size at each site for each season (one tidepool). A similarity percentage (SIMPER) analysis was used to evaluate the contributions of fish species to variations between subtropical and tropical Taiwan. Patterns of variation in intertidal fishes between subtropical and tropical regions were visualized using Principal Coordinates Analysis (PCO) to show the differences based on the PERMANOVA results (Anderson and Willis, 2003). In addition, Pearson's correlation analysis was used to show the most correlated variables (fish species) on the PCO plot. Multivariate analysis and plotting were conducted in Primer-E v.7 (Anderson et al., 2008)

\section{Results and Discussion}

\section{Tidepool fishes overall}

A total of 2648 individuals from 54 species and 17 families were collected from the six sites during the five sampling periods spanning all seasons (Table 1.). Of these, 1298 individuals from 39 species and 13 families were from northern Taiwan and 1350 individuals from 37 species and 12 families were from southern Taiwan. There was no clear difference in species number (richness) between northern and southern Taiwan from rarefaction curves (Figure 2.). Fishes that were abundant in most samples of this study were: Gobiidae (Bathygobius fuscus, Bathygobius cocosensis, Bathygobius coalitus), Blenniidae (Praealticus striatus, Praealticus tanegasimae, Istiblennius dussumieri, Istiblennius lineatus, Istiblennius edentulus) and Pomacentridae (Abudefduf sordidus, Abudefduf vaigiensis). Of the 2648 fishes collected, resident species made up $68 \%$ while transient species, which consisted of only three species (Hypoatherina tsurugae, Chelon macrolepis, Moolgarda cunnesius), made up 32\%. However, these three transient species only occurred in large numbers in one or two tidepools once or twice throughout the whole study. We excluded them from our analyses to focus on resident species only. Surprisingly, the overall abundance and biomass of tidepool fishes was not associated with any given factor (region, season or site, GLMM, Table 2.), even though the average abundance and biomass of fishes were quite different between subtropical (northern) and tropical (southern) Taiwan (Table 3.). Species number was influenced by site only (GLMM, Table 2.). The number of species at both subtropical and tropical sites was around ten for each sampling period (Table 3.).

\section{Species composition}

The species composition of intertidal fish assemblages was significantly different between regions and sites, but not across seasons (PERMANOVA, Table 4.). The difference in species composition between subtropical and tropical areas was driven by higher abundances of Abudefduf notatus, $A$. vaigiensis and $B$. fuscus in the subtropical region (Pearson's correlation analysis, Figure 3). Higher abundances of $B$. coalitus at two of the tropical sites (Checheng and Jioupeng) also contributed to the difference between subtropical and tropical regions. A range of other fishes also contributed to the difference in species composition between subtropical and tropical Taiwan (SIMPER, Table 5). B. fuscus, Blenniella bilitonensis, Blenniella chrysospilos, Enneapterygius etheostomus and 
Omobranchus germaini were collected in subtropical (northern) but not in tropical (southern) Taiwan. Other species like Acanthurus triostegus, Chrysiptera unimaculata, Echidna nebulosa, Ostorhinchus cookii, Scorpaenodes guamensis and Thalassoma purpureum were only collected in tropical Taiwan. These results suggest that some tidepool fish species may have a limited distribution within Taiwan.

While no significant difference was found among sites within subtropical (northern) Taiwan, tropical (southern) Taiwan showed a significant difference in species composition according to site, which was because the species found in one site (Siangjiaowan) were different to those from the other two southern sites (Figure 3.). Siangjiaowan was characterized by many species which were considered to be more subtidal reef species than intertidal species such as Abudefduf septemfasciatus, Chrysiptera glauca, C. unimaculata, E. nebulosa, Halichoeres marginatus, $H$. tsurugae, $O$. cookii, S. guamensis, Stethojulis trilineata and $T$. purpureum.

\section{Trophic functional groups}

The different trophic groups did not share a consistent regional pattern (Figure 4). Herbivores, omnivores and detritivores were found to be the dominant trophic groups in tidepools across Taiwan, being two to three times more abundant than the pooled carnivores. These dominant trophic groups had or showed trends towards higher abundances in subtropical compared to tropical Taiwan, while most carnivores, which included planktivores, benthic invertebrate feeders and general carnivores had or showed trends towards higher abundances in southern, tropical Taiwan (Figure 4a.). Only detritivores and general carnivores showed statistically significant differences in abundances between subtropical and tropical Taiwan. The biomass of the three dominant trophic groups did not vary between regions, while all carnivores either had or showed trends towards higher biomass in tropical compared to subtropical Taiwan (Figure 4b.). Herbivores, planktivores and general carnivores had or showed trends towards higher species numbers in the tropical region compared to the subtropical region (Figure 4c.), but only the planktivores showed statistically significant differences (Table 6). Besides regional differences, only herbivores of tidepool fishes also showed seasonal variations in abundance, biomass and species number (Table 6.), which might relate to seasonal patterns in the availability of their algal food sources (Tsai et al., 2004). In addition, differences according to site (nested within region) were common for herbivores, planktivores, benthic invertebrate feeders and general carnivores for most, if not all, of the measured dependant variables (abundance, biomass and species number). This might suggest that there are different microhabitats which support finer scale variation within intertidal fish communities.

Table 2. Results from the Generalized Linear Mixed Model (GLMM) for total tidepool fishes. The GLMM examined associations of regional, seasonal and site(region) factors on abundance, species number (richness) and biomass of total tidepool fishes.

\begin{tabular}{lccc}
\hline Formula & df & AlCc & $\begin{array}{c}\text { Akaike } \\
\text { weight }\end{array}$ \\
\hline Abundance 1 & 1 & 311.579 & 0.699 \\
Richness Site(Region) & 2 & 155.246 & 0.512 \\
Biomass $\sim 1$ & 1 & 389.365 & 0.653 \\
\hline
\end{tabular}

Table 3. Differences in intertidal fish assemblages between subtropical (northern) and tropical (southern) Taiwan. Data presented are the average $( \pm S E)$ abundances, species numbers (richness) and biomass of tidepool fishes per tidepool for the subtropical and tropical regions. (The numbers for abundance and biomass have been standardized).

\begin{tabular}{lcc}
\hline & Subtropical & Tropical \\
\hline Abundance & $66.4 \pm 15.5$ & $30.9 \pm 8.3$ \\
Richness & $10.5 \pm 1.0$ & $10.9 \pm 1.0$ \\
Biomass & $205.1 \pm 53.4$ & $118.6 \pm 25.2$ \\
\hline
\end{tabular}

Table 4. PERMANOVA results showing the effects of three factors on species composition of intertidal fish assemblages. The three factors were Region (subtropical and tropical), Season (January, April, August and October) and Site (nested within region). Star (*) indicates statistical significance where $\alpha=0.05$.

\begin{tabular}{lrrrrl}
\hline Source & df & \multicolumn{1}{l}{ SS } & MS & Pseudo-F & $p(M C)$ \\
\hline Region & 1 & 2.050 & 2.0500 & 3.0812 & $0.03^{*}$ \\
Season & 3 & 1.034 & 0.3447 & 1.2934 & 0.14 \\
Site(Region) & 4 & 2.642 & 0.6605 & 2.242 & $0.01^{*}$ \\
Region x Season & 3 & 1.005 & 0.3350 & 1.2647 & 0.18 \\
Site(region) x Season & 12 & 3.174 & 0.2645 & 0.89791 & 0.72 \\
Residual & 5 & 1.473 & 0.2946 & & \\
Total & 28 & 11.379 & & & \\
\hline
\end{tabular}


Table 5. SIMPER results showing the species that contributed the most to regional differences in species composition.

\begin{tabular}{|c|c|c|c|c|c|}
\hline Species & $\begin{array}{l}\text { Subtropical } \\
\text { average } \\
\text { abundance }\end{array}$ & $\begin{array}{l}\text { Tropical average } \\
\text { abundance }\end{array}$ & $\begin{array}{c}\text { Average } \\
\text { dissimilarity }\end{array}$ & $\begin{array}{c}\text { Contribution } \\
(\%)\end{array}$ & Cumulative (\%) \\
\hline Bathygobius fuscus & 1.74 & 0 & 5.5 & 7.38 & 7.38 \\
\hline Istiblennius lineatus & 0.82 & 1.46 & 4.17 & 5.6 & 12.98 \\
\hline Chelon macrolepis & 1.31 & 0.26 & 4.07 & 5.46 & 18.44 \\
\hline Bathygobius coalitus & 0.09 & 1.24 & 3.86 & 5.19 & 23.62 \\
\hline Abudefduf vaigiensis & 1.34 & 0.62 & 3.83 & 5.14 & 28.77 \\
\hline Istiblennius dussumieri & 1.23 & 0.11 & 3.77 & 5.06 & 33.83 \\
\hline Istiblennius edentulus & 1.51 & 1.64 & 3.62 & 4.85 & 38.68 \\
\hline Kuhlia mugil & 0.73 & 0.72 & 3.26 & 4.38 & 43.06 \\
\hline Abudefduf sordidus & 1.34 & 1.15 & 3.17 & 4.26 & 47.32 \\
\hline Praealticus striatus & 0.64 & 0.6 & 3.04 & 4.08 & 51.4 \\
\hline Bathygobius cocosensis & 1.27 & 1.06 & 2.99 & 4.02 & 55.41 \\
\hline Praealticus tanegasimae & 0.9 & 0.16 & 2.84 & 3.8 & 59.22 \\
\hline Abudefduf septemfasciatus & 0.05 & 0.76 & 2.49 & 3.35 & 62.56 \\
\hline Chrysiptera unimaculata & 0 & 0.7 & 2.11 & 2.83 & 65.4 \\
\hline Chrysiptera glauca & 0.07 & 0.61 & 1.92 & 2.58 & 67.97 \\
\hline Scorpaenodes guamensis & 0 & 0.61 & 1.67 & 2.24 & 70.22 \\
\hline Ostorhinchus cookii & 0 & 0.54 & 1.53 & 2.05 & 72.26 \\
\hline Thalassoma purpureum & 0 & 0.49 & 1.44 & 1.93 & 74.2 \\
\hline Entomacrodus striatus & 0.43 & 0.1 & 1.33 & 1.78 & 75.98 \\
\hline Enneapterygius etheostomus & 0.45 & 0 & 1.27 & 1.7 & 77.68 \\
\hline Acanthurus triostegus & 0 & 0.44 & 1.25 & 1.68 & 79.36 \\
\hline Stethojulis trilineata & 0.18 & 0.35 & 1.23 & 1.64 & 81 \\
\hline Omobranchus germaini & 0.39 & 0 & 1.1 & 1.48 & 82.48 \\
\hline Bathygobius cotticeps & 0.3 & 0.24 & 1.06 & 1.43 & 83.91 \\
\hline Echidna nebulosa & 0 & 0.4 & 0.97 & 1.3 & 85.21 \\
\hline Bathygobius cyclopterus & 0.28 & 0.05 & 0.9 & 1.21 & 86.42 \\
\hline Blenniella chrysospilos & 0.23 & 0 & 0.84 & 1.13 & 87.54 \\
\hline Abudefduf notatus & 0.26 & 0.05 & 0.8 & 1.08 & 88.62 \\
\hline Blenniella bilitonensis & 0.23 & 0 & 0.76 & 1.02 & 89.64 \\
\hline Praealticus margaritarius & 0.09 & 0.11 & 0.7 & 0.94 & 90.58 \\
\hline
\end{tabular}

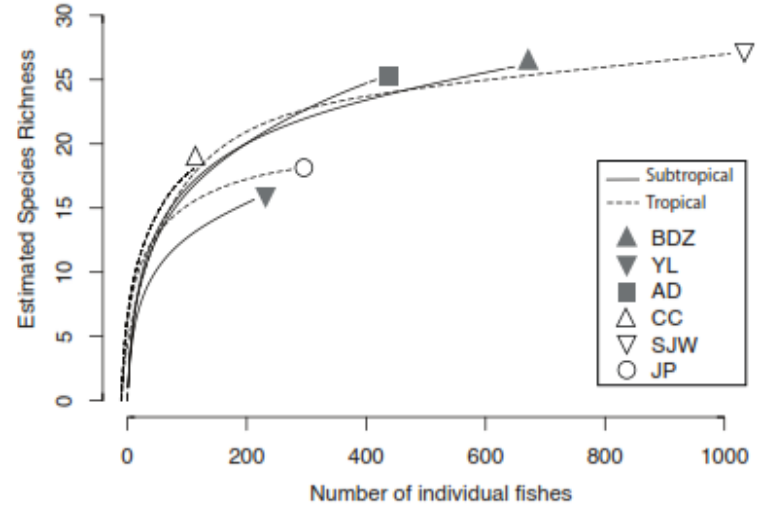

Figure 2. Rarefaction curves of tidepool fish species richness in subtropical (solid lines) and tropical (dotted lines) Taiwan.

This study is a spatial and temporal survey of intertidal fishes from northern and southern Taiwan, spanning subtropical and tropical zones of the western Pacific Ocean. Our quantitative data on intertidal fishes and their trophic groups (from dietary analysis) serves as a baseline record of species composition, abundance, biomass and species numbers for subtropical and tropical coasts in the western Pacific.

We did not find statistically significant differences in regional and seasonal patterns of abundance, biomass or species richness overall for resident tidepool fishes in Taiwan, despite the fact that the averages were quite different between the two regions. This may be due to differences in microhabitats across each site, which support different fish communities. Our analysis of the species composition of tidepool fish assemblages in Taiwan supports this, as we found significant differences in species compositions between subtropical and tropical Taiwan and differences between a couple of sampling sites. 
The regional differences in the species composition of tidepool fish assemblages are consistent with other studies on shallow water and subtidal fishes (e.g. Shao et al., 2002; Hsiao et al., 2011). Interestingly, pairs of species within the same genera were occurring in parallel in subtropical and tropical Taiwan. For example, Bathygobius fuscus (Gobiidae) was abundant in northern (subtropical) Taiwan but was not found in the south whereas $B$. coalitus was abundant in the south but very rare in the north. Other examples of this also occurred in Blenniidae (Istiblennius dussumieri in the north vs. I. lineatus in the south) and Pomacentridae (Abudefduf vaigiensis in the north vs. A. septemfasciatus in the south). These sister species are also very similar in appearance. These species pairs may be good models for investigating sympatric speciation in rocky intertidal ecosystems in the Indo-Pacific region. However, more molecular evidence is needed for an informed discussion about sympatric evolutionary patterns in these species (e.g. Horne and van Herwerden, 2013).

By synthesizing our findings with the existing literature on intertidal fishes in the Pacific (Table 7.), we paint a more comprehensive picture of broader regional patterns in intertidal fishes. We only examine the spatial patterns for Pacific tidepool/intertidal fishes here (Table 7.) because the species compositions of rocky intertidal fish assemblages are quite different between oceanographic regions (Prochazka et al., 1999). Our study found that Blenniidae, Gobiidae and Pomacentridae were the dominant families of intertidal fishes in Taiwan. These findings complement those of other studies on intertidal fishes that have been done in subtropical (Japan, Arakaki and Tokeshi, 2006; Arakaki et al., 2014; Murase, 2015; Okada et al., 2015) and tropical (Hawai'i, Cox et al., 2011) areas of the Pacific. Our synthesis of the available information shows that Blenniidae and Gobiidae are the two most dominant families among rocky intertidal fishes across different latitudes on Pacific coasts and islands (Table 7.). In addition, Pomacentridae is an abundant family in tropical/subtropical tidepools (Taiwan, Hawai'i and Colombia), but its abundance decreases towards higher latitudes (Japan and Australia). At higher latitudes, Tripterygiidae becomes more abundant on coasts in the western Pacific and Cottidae becomes more abundant on coasts in the eastern Pacific.

We compared our data with the literature on intertidal fishes around the Pacific Ocean (Table 7.) to examine the theory from Hillebrand (2004a) that biodiversity will increase with proximity to the equator. Comparisons between studies should be treated with caution however, due to potentially different interpretations of resident and transient

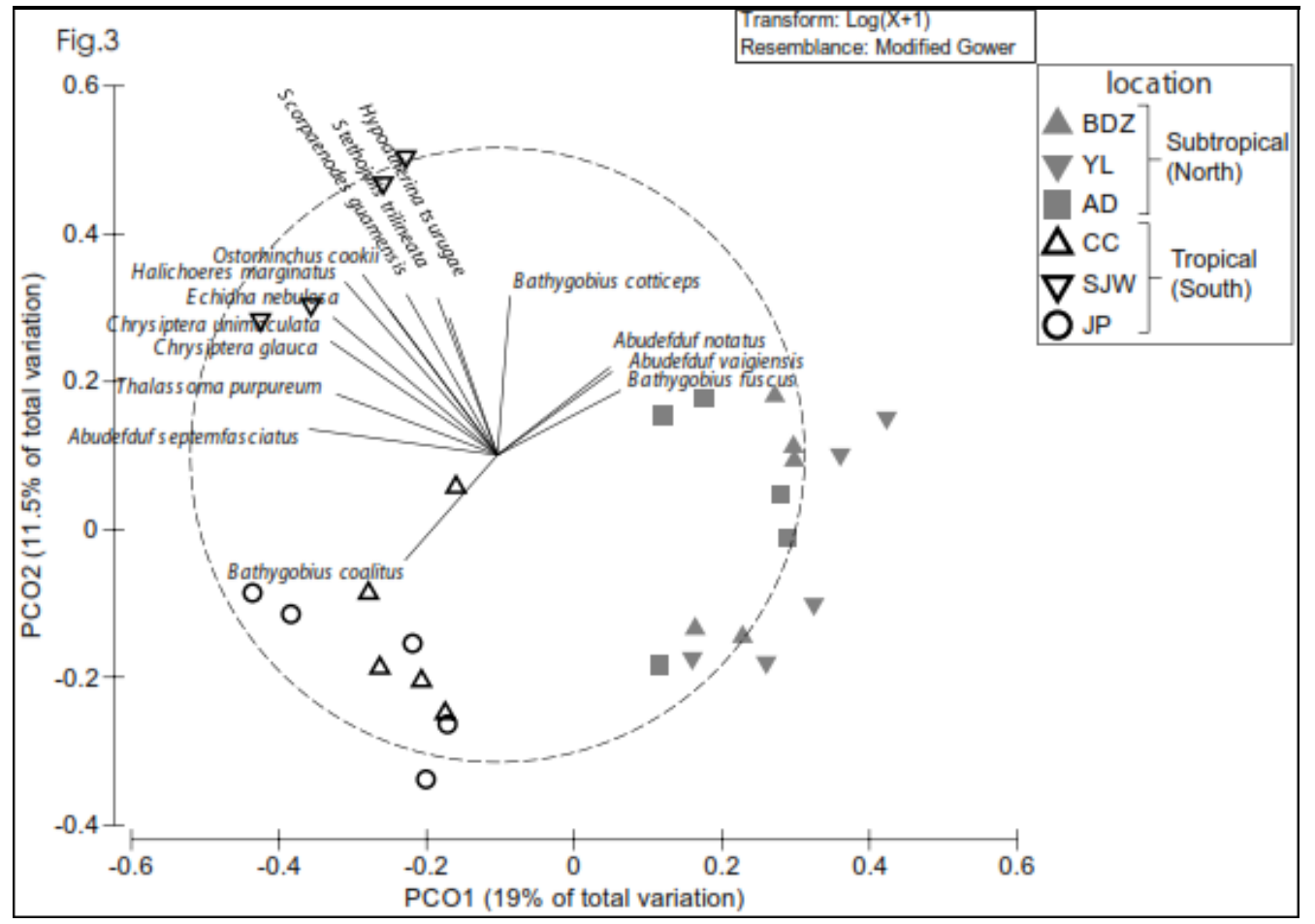

Figure 3. Principal Coordinates Analysis (PCO) plot showing variation in intertidal fishes between subtropical and tropical Taiwan. 


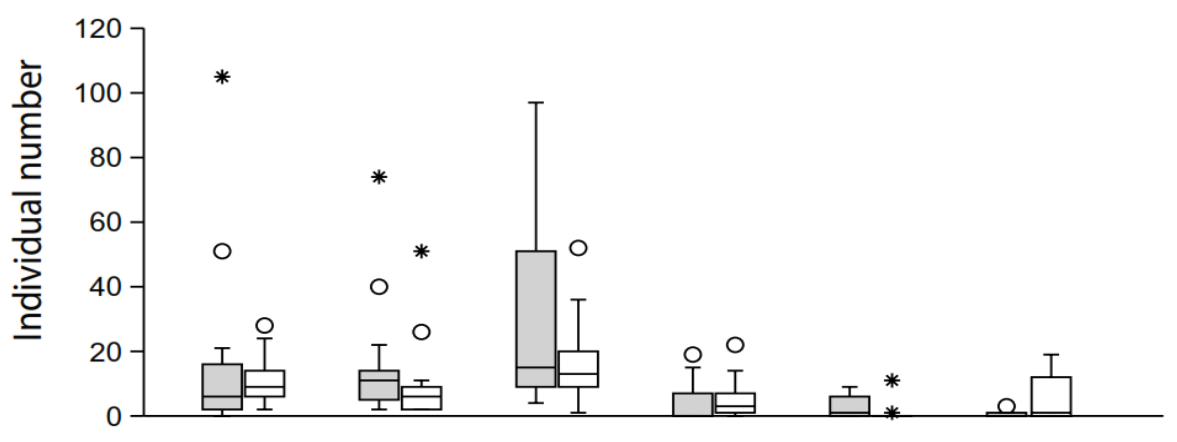

(a)

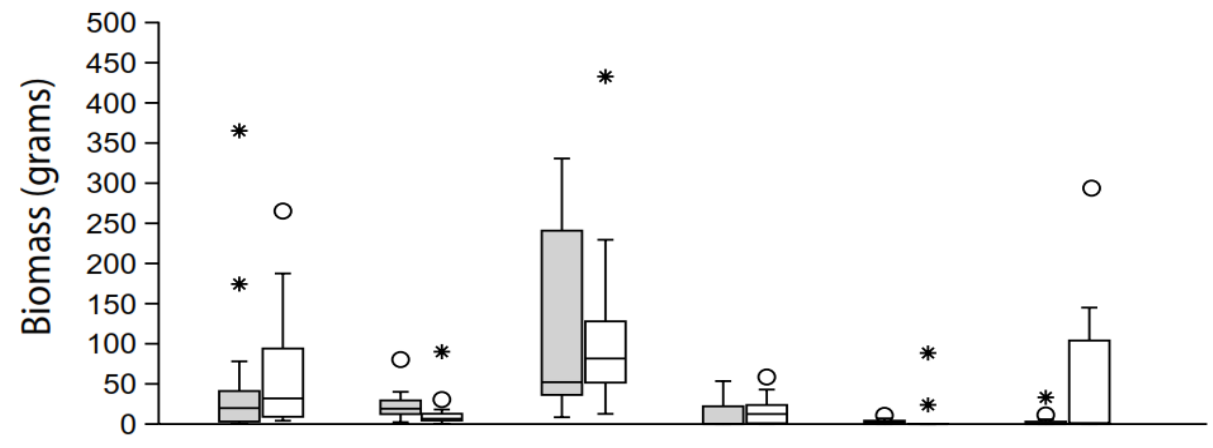

(b)

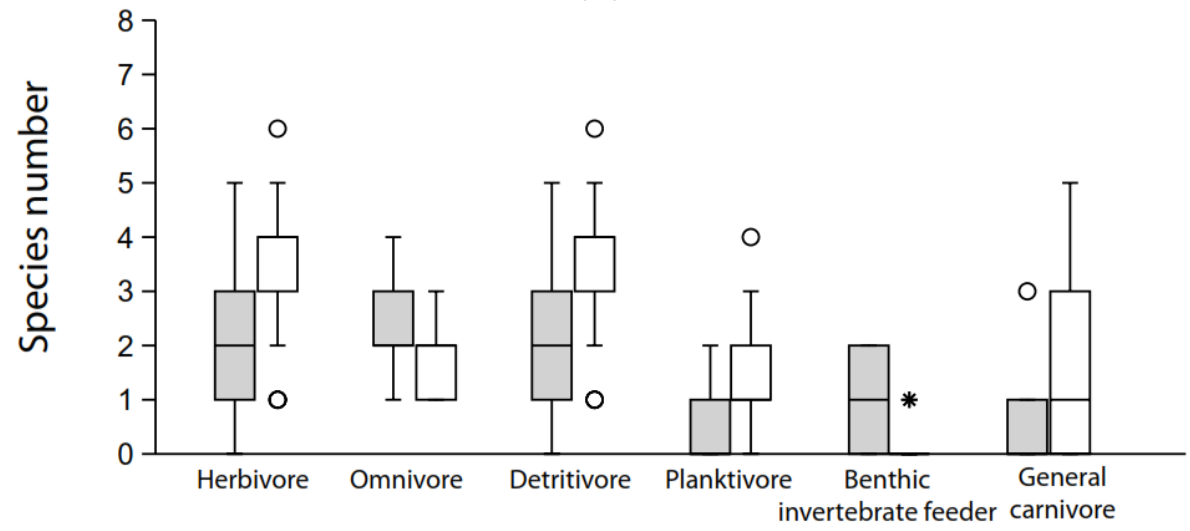

(c)

Figure 4. Boxplots of (a) abundance, (b) biomass and (c) species number for the trophic groups of intertidal fishes in both subtropical (northern) and tropical (southern) Taiwan. Lines within the boxes represent medians, and the upper and lower boundaries of the boxes represent $25^{\text {th }}$ and $75^{\text {th }}$ percentiles. Whiskers outside the boxes indicate the largest data point less than 1.5 times the box height. Circle symbols ${ }^{\circ}$ on the boxplots represent outliers outside the inner fence of box, star symbol * represent the value more than 3 times the box height.

species, sampling of tidepools at different vertical heights from the low tide line, and some tidepool volumes having to be approximated based on the data available in the literature. Species richness of resident tidepool fishes in the tropics/subtropics of the western Pacific (around 2.9/3.1 species per $\mathrm{m}^{3}$, this study; around 0.69 species per $\mathrm{m}^{3}$, Murase, $2015)$ is higher than in the tropical eastern Pacific (0.63 species per $\mathrm{m}^{3}$, Castellanos-Galindo et al. 2005), the tropical central Pacific (around 0.39 species per $\mathrm{m}^{3}$, Cox et al., 2011), and the temperate Pacific (around 0.17 species per $\mathrm{m}^{3}$ Griffiths 2002; Griffiths et al., 2003). A similar pattern arises if all collected samples are considered, including resident, transient and rare species, with subtropical tidepools having the highest species number (3.25 species per $\mathrm{m}^{3}$, this study; 3.56 species per $\mathrm{m}^{3}$, Murase, 2015), followed by tropical tidepools (3.1 species per $\mathrm{m}^{3}$, this study; 2.9 species per $\mathrm{m}^{3}$, Castellanos-Galindo et al. 2005; 0.83 species per 
$\mathrm{m}^{3}$, Cox et al., 2011), and temperate rocky tidepools having the lowest species number of all studies (0.71 species per $\mathrm{m}^{3}$, Griffiths, 2002; Griffiths et al., 2003). For intertidal fishes in the Pacific, it therefore appears that there is not a clear gradient of increasing biodiversity towards the equator, and that region, rather than latitude, may be a better predictor of species richness. The western Pacific appears to have the highest number of intertidal fish species of all the Pacific regions.

In this study, we found a higher abundance and biomass of carnivores (with the exception of benthic invertebrate feeders) in the tropics

Table 6. Results from the Generalized Linear Mixed Models (GLMMs) for trophic groups. Models with poisson, negative binomial, and zero-inflation assumptions were used to examine associations of regional and seasonal factors on abundance, biomass and species number for each trophic group of tidepool fishes.

\begin{tabular}{|c|c|c|c|c|}
\hline Trophic group & Best fit model & Model family & $\mathrm{AICc}$ & $\begin{array}{l}\text { Akaike } \\
\text { weight }\end{array}$ \\
\hline \multicolumn{5}{|l|}{ Abundance } \\
\hline Herbivore & Season & GLNB & 215.114 & 0.392 \\
\hline Omnivore & NULL & GLNB & 212.764 & 0.305 \\
\hline Detritivore & Region & GLNB & 242.217 & 0.370 \\
\hline Planktivore & Site(Region) & ZINB & 148.557 & 0.563 \\
\hline Benthic invertebrate feeder & NULL & ZINB & 95.067 & 0.329 \\
\hline General carnivore & Region+Site(Region) & GLMM.ZIP & 90.524 & 0.640 \\
\hline \multicolumn{5}{|l|}{ Biomass } \\
\hline Herbivore & Season+Site(Region) & GLMM.NB & 291.060 & 0.485 \\
\hline Omnivore & NULL & GLNB & 233.363 & 0.318 \\
\hline Detritivore & NULL & GLNB & 337.600 & 0.574 \\
\hline Planktivore & Region+Site(Region) & GLMM.ZINB & 117.550 & 0.966 \\
\hline Benthic invertebrate feeder & Site(Region) & GLMM.ZINB & 113.561 & 0.690 \\
\hline General carnivore & Site(Region) & GLMM.ZINB & 92.911 & 0.540 \\
\hline \multicolumn{5}{|l|}{ Species number } \\
\hline Herbivore & Season+Site(Region) & GLMM.NB & 291.060 & 0.485 \\
\hline Omnivore & NULL & GLNB & 233.363 & 0.318 \\
\hline Detritivore & NULL & GLNB & 337.257 & 0.570 \\
\hline Planktivore & Region+Site(Region) & GLMM.ZLNB & 177.773 & 0.964 \\
\hline Benthic invertebrate feeder & Site(Region) & GLMM.ZINB & 115.868 & 0.894 \\
\hline General carnivore & Site(Region) & GLMM.ZIP & 75.848 & 0.343 \\
\hline
\end{tabular}

Table 7. Dominant families of rocky tidepool fishes in three broad Pacific regions. Dominant families were determined from this study and the scientific literature. The numbers in brackets represent abundances as a percentage of all tidepool fishes in that location. (NA= percentage not available).

\begin{tabular}{|c|c|c|c|}
\hline Region & Location & Dominant families & Reference \\
\hline Tropical (western Pacific) & Taiwan & $\begin{array}{l}\text { Blenniidae (34\%), Gobiidae (21\%), } \\
\text { Pomacentridae (20\%) }\end{array}$ & This study \\
\hline Tropical (central Pacific) & Hawai'i & $\begin{array}{l}\text { Gobiidae (34\%), Blenniidae (19\%), } \\
\text { Pomacentridae (16\%) }\end{array}$ & (Cox et al., 2011) \\
\hline Tropical (eastern Pacific) & Colombia & Gobiidae (55\%), Pomacentridae (21\%) & $\begin{array}{l}\text { (Castellanos-Galindo et } \\
\text { al., 2005) }\end{array}$ \\
\hline Subtropical (western Pacific) & Taiwan & $\begin{array}{l}\text { Blenniidae (42\%), Gobiidae (24\%), } \\
\text { Pomacentridae (24\%) }\end{array}$ & This study \\
\hline Subtropical (western Pacific) & Shikizaki, Japan & Gobiidae (94\%) & $\begin{array}{l}\text { (Arakaki and Tokeshi, } \\
\text { 2006) }\end{array}$ \\
\hline Subtropical (western Pacific) & Yaku-shima, Japan & Blenniidae (49\%), Gobiidae (32\%) & (Murase, 2015) \\
\hline $\begin{array}{l}\text { Subtropical/temperate } \\
\text { (eastern Pacific) }\end{array}$ & $\begin{array}{l}\text { California, United } \\
\text { States of America }\end{array}$ & Cottidae (60\%) & (Yoshiyama et al., 1986) \\
\hline Temperate (eastern Pacific) & $\begin{array}{l}\text { California, United } \\
\text { States of America }\end{array}$ & $\begin{array}{l}\text { Cottidae (NA), Stichaeldae (NA), } \\
\text { Gobiesocidae (NA) }\end{array}$ & (Boyle and Horn, 2006) \\
\hline Temperate (eastern Pacific) & Chile & $\begin{array}{l}\text { Blenniidae, Tripterygiidae, Larisomidae, } \\
\text { Kyphosidae ( } 20 \% \text { for each) }\end{array}$ & $\begin{array}{l}\text { (Munoz and Ojeda, } \\
\text { 1997) }\end{array}$ \\
\hline Temperate (western Pacific) & Australia & Gobiidae (45\%), Tripterygiidae (27\%) & (Griffiths et al., 2003) \\
\hline
\end{tabular}


compared to the subtropics. This regional trend of tidepool carnivorous fishes is consistent with latitudinal patterns that have been found for trophic groups in other ecosystems (Hillebrand, 2004a). Conversely, we found that there were less herbivores, omnivores and detritivores in the tropics. These findings suggest that the principle of increasing abundance with proximity to the equator does not hold for all trophic groups of tidepool fishes in Taiwan, and this could potentially be the case more broadly across the western Pacific. However, the inaccessibility of non-English records, and limited studies examining intertidal fish trophic groups in this region may introduce a bias to this observation.

Based on biomass and abundance, detritivores are the major trophic functional group in the intertidal zone of subtropical and tropical Taiwan as well as in other regions (Hundt et al., 2014). Despite the relatively small size of most detritivorous species, they have a large biomass overall compared to other trophic groups because of their high numbers. Notably, Blenniidae which are generally small in size were very numerous in our survey data. Detritus and filamentous algae were the two most common food items in the gut contents of Blenniidae, which is in line with findings from other studies on intertidal blennies (Wilson, 2000; Castellanos-Galindo and Giraldo, 2008). Detritus is often found in the diet of benthic fishes, but may be consumed incidentally while they are feeding on infauna (Gerking, 1994). However, Wilson (2000) and Wilson et al. (2001) suggest that detritus is a rich nitrogen and lipid resource for subtidal coral blennies (Salarias patzneri). Given the likely nutritional benefit of detritus for Blenniidae, and that we found the gut contents of tidepool blennies on average consisted of twice as much detritus as algae, we categorized them as detritivores. Other methods for identifying diet, such as stable isotope analysis, could be employed to ascertain Blenniidae's trophic group in future (e.g. Ho et al., 2007). Detritivorous fishes play an important role in transferring nutrients from detritus into higher trophic levels within reef ecosystems (Wilson et al. 2003). The predominance of detritivorous blennies within tidepools around Taiwan means this family is likely a strong contributor to nutrient transfer, and plays an important role in the trophodynamics of intertidal assemblages.

Herbivores, mainly Pomacentridae and Acanthuridae, were second to detritivores as the most dominant trophic functional group in terms of abundance, biomass and species number. This is in contrast to other studies of trophic structures in intertidal fishes, which have tended to show carnivorous species as being the most numerous (Munoz and Ojeda, 1997; Velasco et al., 2010).
These studies examined fishes in temperate regions however, where herbivory is expected to be less common (Gibson and Yoshiyama, 1999). We found that the abundance of herbivores in subtropical Taiwan was higher than in tropical Taiwan, but the species number was higher in tropical Taiwan. One explanation for the higher abundance of herbivores in the subtropical region could be higher algal abundance. Algal abundance and coverage was not surveyed in this study, but Wen et al. (2013) showed that macroalgae occurs in higher abundance in subtropical compared to tropical shallow reefs. The most common macroalgae that we found in the gut contents of herbivores (i.e. Cladophora spp., Centroceras spp., Sphacelaria spp., Chaetomopha spp., Hypnea spp., Gelidium spp., Ulva spp. and Enteromorpha spp.) are also more abundant in subtropical Taiwan lending support to this explanation (Tsai et al., 2004). In contrast to our findings, herbivores on coral reefs have been shown to be more abundant as well as account for higher biomass in tropical regions compared to subtropical and temperate regions, despite there being less macroalgae in the tropics (Meekan and Choat, 1997). Many rational explanations have been suggested for this, for example, macroalgae in tropical regions can be easier to digest and have a higher energy content (reviews in Horn, 1989). Yet, no solid conclusions from studies on the interaction between intertidal herbivores and algae have been made. This may be because coastal eutrophication from human activities has changed the abundance and biomass of coastal algae globally, which makes it difficult to examine the relationship between herbivores and algae in intertidal areas without biases (Burkepile and Hay, 2006).

We detected minimal significant seasonal variations in species composition, abundance, biomass and species number for intertidal fishes and their trophic functional groups in subtropical and tropical Taiwan. This is in contrast to many studies on coral reef fishes which have indicated seasonal variations in movement, composition and recruitment of fishes due to seasonal fluctuations in environmental parameters or food availability (Abesamis and Russ, 2010; Bijoux et al., 2013; Okazaki et al., 2012). With respect to intertidal fishes however, overall our results are in line with other studies which show stable species diversity in subtropical and tropical tidepool fish assemblages across seasons (Castellanos-Galindo et al., 2005; Murase, 2013). We observed some transient species in large numbers in one or two of our samples, suggesting seasonal variation. However, these species did not appear in other sites in the same region, hence there is no conclusive evidence of seasonal variation in these species. It may be that the species composition of intertidal fish 
assemblages can remain stable across seasons because the diet of these fishes might shift as food (macroalgae and invertebrate) availability changes. Such dietary shifts could explain why seasonal stability in species diversity has also been found for tidepool fishes in other parts of the Pacific (e.g. Castellanos-Galindo et al., 2005; Murase, 2013). Indeed, benthic macroalgae and other invertebrates which are food sources for fishes show significant seasonal variation in subtropical and tropical Taiwan (Tsai et al. 2004; Shieh and Chi 2010). A closer examination of the diets of intertidal fishes across time may reflect these seasonal patterns.

Due to the temporary and patchy nature of tidepools, it was a challenge to quantify fish abundance and diversity, as uncontrollable factors may introduce bias. The fishes we collected from tidepools were used to represent the abundance and diversity of intertidal fish assemblages. Although Arakaki and Tokeshi (2006) did not find significant differences between captured samples and underwater visual census (UVC) data on temperatesubtropical intertidal fishes, the possibility that we missed some resident species during fish collection cannot be ignored. For instance, in an exploratory survey using UVC during high tide, we saw more mobile fishes such as Pomacentridae and Labridae in the intertidal zone, but much fewer resident species like Gobiidae and Blenniidae (Wen pers. obs.). This suggests that mobile species will migrate with the tides and resident species are too cryptic to be observed by UVC. Collection of tidepool fishes was chosen for our purpose because these cryptic fishes are less studied as compared to the mobile species commonly surveyed in other subtidal studies. In addition, the size of the tidepool may affect species composition. For example, the site Siangjiaowan, where the tidepool was unavoidably twice the size of those at other sites, had more carnivores and larger individuals. However, the difference between northern (subtropical) and southern (tropical) Taiwan was consistent across all sites.

Many logistical and physical obstacles inherent in the study of intertidal fishes have made this an under-studied area of research. This is problematic, because with increasing coastal development and human activity, the impacts on intertidal fish assemblages are dramatically increasing. Very limited impact assessments can be done on intertidal fishes due to the lack of long-term studies and baseline data. For example, one site used in this study (Aodi) is only $50 \mathrm{~m}$ from breakwaters (Wen et al., 2010), and even though the tidepool we chose seems to be in a natural, unaffected condition, the potential influence from nearby human activities were unknown. The intertidal habitat examined in Wen et al. (2010) has since disappeared but the lack of historical data for a comprehensive before-after-control-impact study makes it difficult to illustrate the loss. Likewise, only a few studies have been published on the Indowestern Pacific Ocean biodiversity hotspot. Little is known about the geographical (latitudinal or longitudinal) patterns of intertidal fishes in the Indowestern Pacific region compared to the eastern Pacific. While the present study makes headway in this regard, more studies on intertidal fishes are encouraged to build up a baseline of data, which will assist in measuring and understanding potential future impacts from human disturbance.

\section{Acknowledgments}

This manuscript is based on CW's master thesis while supervised by LC and KS. Funding for this study was provided by the Biodiversity Research Center, Academia Sinica. We are grateful to many people who assisted in fieldwork and laboratory work, particularly L. T. Ho, S. C. Wang, P. L. Lin, N. J. Lee, and S. L. Feng. We deeply appreciate the editing input and advice from S. J. Heatwole, J. Leis and L. Castell on manuscript drafts.

\section{References}

Abesamis, R. \& Russ, G. 2010. Patterns of recruitment of coral reef fishes in a monsoonal environment. Coral Reefs. 29:911-921. doi: 10.1007/s00338-010-0653-y

Afeworki, Y., Videler, J.J. \& Bruggemann, J.H. 2013. Seasonally changing habitat use patterns among roving herbivorous fishes in the southern Red Sea: the role of temperature and algal community structure. Coral Reefs. 32:475-485. doi: $10.1007 /$ s0033 8-012-100 $0-2$

Allen, G., Steene, R., Humann, P. \& DeLoach, N. 2003. Reef fish identification: tropical Pacific. New World Publications, Florida

Anderson, M.J. 2001. A new method for nonparametric multivariate analysis of variance. Austral. Ecol. 26:32-46. doi: 10.1111/j.14429993.2001.01070.pp.x

Anderson, M.J., Ellingsen, K.E. \& McArdle, B.H. 2006. Multivariate dispersion as a measure of beta diversity. Ecol. Lett. 9:683-693. doi: 10.1111/ j.1461-0248.2006.00926.x 
Anderson, M.J., Gorley, R.N. \& Clarke, K.R. 2008. PERMANOVA+ for PRIMER: guide to software and statistical methods. Primer-E, Plymouth, UK, 237.

Anderson, M.J. \& Millar, R.B. 2004. Spatial variation and effects of habitat on temperate reef fish assemblages in northeastern New Zealand. J. Exp. Mar. Biol. Ecol. 305:191-221 doi: 10.1016 /j.jembe.2003.12.011

Anderson, M.J. \& Willis, T.J. 2003. Canonical analysis of principal coordinates: a useful method of constrained ordination for ecology. Ecology. 84:511-525 doi: 10.1890/00129658(2003)084[0511:CAOPCA]2.0.C0;2

Arakaki, S. \& Tokeshi, M. 2006. Short-term dynamics of tidepool fish community: diel and seasonal variation. Environ. Biol. Fish. 76:221-235 doi: doi: 10.1007/s10641-006-9024-5

Arakaki, S., Tsuchiya, M. \&Tokeshi, M. 2014. Testing latitudinal patterns of tidepool fish assemblages: local substrate characteristics affect regional-scale trends. Hydrobiologia. 733:45-62. doi: 10.1007/s10750-013-1768-2

Bellwood, D.R. \& Hughes, T.P. 2001. Regional-scale assembly rules and biodiversity of coral reefs. Science. 292:1532-1535 doi: 10.1126/scie nce. 1058635

Bellwood, D.R., Hughes, T.P., Connolly, S.R. \& Tanner, J. 2005. Environmental and geometric constraints on Indo-Pacific coral reef biodiversity. Ecol. Lett. 8:643-651 doi: 10.1111/j.1461-0248.2005.00763.x

Bijoux, J.P., Dagorn, L., Gaertner, J.C., Cowley, P.D. \& Robinson, J. 2013. The influence of natural cycles on coral reef fish movement: implications for underwater visual census (UVC) surveys. Coral Reefs. 32:1135-1140. doi: 10.1007/s00338-013-1075-4

Bojarska, K. \& Selva, N. 2012. Spatial patterns in brown bear Ursus arctos diet: the role of geographical and environmental factors. Mammal. Rev. 42:120-143 doi: 10.1111 /j.1365-2907.2011.00192.x

Boyle, K.S. \& Horn, M.H. 2006. Comparison of feeding guild structure and ecomorphology of intertidal fish assemblages from central California and central Chile. Mar. Ecol. Prog. Ser. 319:65-84. doi: 10.3354/meps319065

Bulleri, F. 2005. Role of recruitment in causing differences between intertidal assemblages on seawalls and rocky shores. Mar. Ecol. Prog. Ser. 287:53-64. doi: 10.3354/meps287053

Bulleri, F. \& Chapman, M.G. 2010. The introduction of coastal infrastructure as a driver of change in marine environments. J. Appl. Ecol. 47:26-35 doi: 10.1111/j.1365-2664.2009.01751.x

Burkepile, D.E. \& Hay, M.E. 2006. Herbivore vs. nutrient control of marine primary producers: context-dependent effects. Ecology. 87:31283139 doi: 10.1890/0012-9658(2006)87[31 28:HVNCOM]2.0.CO;2

Burt, J.A., Bartholomew, A., Usseglio, P., Bauman, A. \& Sale, P. 2009. Are artificial reefs surrogates of natural habitats for corals and fish in Dubai, United Arab Emirates? Coral Reefs. 28:663675. doi: 10.1007/s00338-009-0500-1

Carnicer, J. \& Díaz-Delgado, R. 2008. Geographic differences between functional groups in patterns of bird species richness in North America. Acta. Oecol. 33:253-264 doi: https://doi.org/10.1016/j.actao.2007.12.001

Castellanos-Galindo, G.A., Giraldo, A. \& Rubio, A.A. 2005. Community structure of an assemblage of tidepoolfishes on a tropical eastern Pacific rocky shore, Colombia. J. Fish. Biol. 67:392408 doi: 10.1111/j.0022-1112.2005.00735.x

Castellanos-Galindo, G.A. \& Giraldo, A. 2008. Food resource use in a tropical eastern Pacific tidepool fish assemblage. Mar. Biol. 153:10231035 doi: 10.1007/s00227-007-0874-y

Chao, A., Gotell, N.J., Hsieh, T.C., Sander, E.L., Ma, K.H., Colwell, R.K. \& Ellison AM 2014. Rarefaction and extrapolation with Hill numbers: a framework for sampling and estimation in species diversity studies. Ecol. Monogr. 84:45-67. doi: 10.1890/13-0133.1

Chen, C.A. \& Shashank, K. 2009. Taiwan as a connective stepping-stone in the Kuroshio Triangle and the conservation of coral ecosystems under the impacts of climate change. Kuroshio Science 3:15-22

Chen, J.P. \& Shao, K.T. 2010. Marine fishes in Kenting National Park. Kenting National Park Headquarters, 650 p. (in Chinese)

Colwell, R.K., Chao, A., Gotelli, N.J., Lin, S.Y., Mao, C.X., Chazdon, R.L. \& Longino, J.T. 2012. Models and estimators linking individual-based and sample-based rarefaction, extrapolation 
and comparison of assemblages. J. Plant. Ecol. 5:3-21. doi: 10.1093/jpe/rtr044

Cox, T., Baumgartner, E., Philippoff, J. \& Boyle, K. 2011. Spatial and vertical patterns in the tidepool fish assemblage on the island of O`ahu. Environ. Biol. Fishes. 90:329-342 doi: 10.1007/s10641-010-9744-4

Dawson, M.N. \& Hamner, W.M. 2008. A biophysical perspective on dispersal and the geography of evolution in marine and terrestrial systems. J. $R$. Soc. Interface. 5:135-150 doi: 10.1098/rsif. 2007.1089

Davies, G.M. \& Gray, A. 2015.) Don't let spurious accusations of pseudoreplication limit our ability to learn from natural experiments (and other messy kinds of ecological monitoring). Ecol. Evol. 5:5295-5304. doi: 10.10 02/ece3.1782

Díaz-Ruiz, F., Delibes-Mateos, M., García-Moreno, J.L., López-Martín, J.M., Ferreira, C. \& Ferreras, P. 2013. Biogeographical patterns in the diet of an opportunistic predator: the red fox Vulpes vulpes in the Iberian Peninsula. Mammal. Rev. 43:59-70 doi: 10.1111/j.1365-2907.2011. 00206.x

Ellis, W.L. \& Bell, S.S. 2013. Intertidal fish communities may make poor indicators of environmental quality: lessons from a study of mangrove habitat modification. Ecol. Indic. 24:421-430 doi: 10.1016/j.ecolind.2012.07. 008

Feller, I.C., Chamberlain, A.H., Piou, C., Chapman, S. \& Lovelock, C.E. 2013. Latitudinal patterns of herbivory in mangrove forests: consequences of nutrient over-enrichment. Ecosystems. 16: 1203-1215 doi: 10.1007/s100 21-013-96788

Floeter, S.R., Behrens, M.D., Ferreira, C.E.L., Paddack, M.J. \& Horn, M.H. 2005. Geographical gradients of marine herbivorous fishes: patterns and processes. Mar. Biol. 147:14351447 doi: 10.1007/s00227-005-0027-0

Gaston, K.J. 2000. Global patterns in biodiversity. Nature. 405:220-227 doi: 10.1038/35012228

Gerking, S.D. 1994. Feeding ecology of fishes. Academic Press, London

German, D.P. \& Horn, M.H. 2006. Gut length and mass in herbivorous and carnivorous prickleback fishes (Teleostei: Stichaeidae): ontogenetic, dietary, and phylogenetic effects.
Mar. Biol. 148:1123-1134. doi: 10.1007/s00 227-005-0149-4

Gibson, R. \& Yoshiyama, R. 1999. Intertidal fish communities. In: Horn MH, Martin KLM, Chotkowski MA (eds) Intertidal fishes: life in two worlds. Academic Press, San Diego

Gillet, R. 2011. Fisheries of the Pacific Islands: regional and national information. Food and Agriculture Organization of the United Nations, Regional Office for Asia and the Pacific, Bangkok.

González-Bergonzoni, I., Meerhoff, M., Davidson, T.A., Teixeira-de Mello, F., Baattrup-Pedersen, A. \& Jeppesen, E. 2012. Meta-analysis shows a consistent and strong latitudinal pattern in fish omnivory across ecosystems. Ecosystems 15:492-503 doi: 10.1007/ s10021-012-95244

Gosliner, T.M., Behrens, D.W. \& Williams, G.C. 1996. Coral reef animals of the Indo-Pacific: animal life from Africa to Hawaii exclusive of the vertebrates. Monterey, Sea Challengers

Griffiths, S.P. 2002. Structure and dynamics of rockpool fish assemblages in southeastern Australia. Ph.D. thesis, Environmental Science, University of Wollongong, 316 p.

Griffiths, S.P. 2003. Rockpool ichthyofaunas of temperate Australia: species composition, residency and biogeographic patterns. Est. Coast. Shelf. Sci. 58:173-186. doi: 10.1016 /s0272-7714(03)00073-8

Griffiths, S.P., West, R.J. \& Davis, A.R. 2003. Effects of intertidal elevation on the rockpool ichthyofaunas of temperate Australia. Environ. Biol. Fishes. 68:197-204 doi: 10.1023/B:EBFI. $0000003870.76842 . \mathrm{d} 0$

Hammer, Ø., Harper, D.A.T. \& Ryan, P.D. 2001. PAST: paleontological statistics software package for education and data analysis. Palaeontol. Electron. 4:1-9

Harriott, V. \& Banks, S. 2002. Latitudinal variation in coral communities in eastern Australia: a qualitative biophysical model of factors regulating coral reefs. Coral Reefs. 21:83-94. doi: 10.1007/s00338-001-0201-x

Hillebrand, H. 2004a. On the generality of the latitudinal diversity gradient. Am. Nat. 163:192211. doi: $10.1086 / 381004$ 
Hillebrand, H. 2004b. Strength, slope and variability of marine latitudinal gradients. Mar. Ecol. Prog. Ser. 273:251-267. doi:10.3354/meps273251

Ho, C.T., Kao, S.J., Dai, C.F., Hsieh, H.L., Shiah, F.K. \& Jan, R.Q. 2007. Dietary separation between two blennies and the Pacific gregory in northern Taiwan: evidence from stomach content and stable isotope analyses. Mar. Biol. 151:729736. doi: 10.1007/s00227-006-05 17-8

Horn, M.H. 1989. Biology of marine herbivorous fishes. Oceanogr. Mar. Biol. Annu. Rev. 27:167272

Horn, M.H., Martin, K.L.M. \& Chotkowski, M.A. (eds) 1999. Intertidal fishes: life in two worlds. Academic Press, San Diego

Horn, M. \& Ojeda, F. 1999. Herbivory. In: Horn MH, Martin KLM, Chotkowski MA (eds) Intertidal fishes: life in two worlds. Academic Press, San Diego

Horne, J.B. \& van Herwerden, L. 2013. Long-term panmixia in a cosmopolitan Indo-Pacific coral reef fish and a nebulous genetic boundary with its broadly sympatric sister species. J. Evol. Biol. 26: 783-799 doi: 10.1111/jeb.12092

Hsiao, S.H., Fang, T.H., Shih, C.T. \& Hwang, J.S. 2011. Effects of the Kuroshio Current on copepod assemblages in Taiwan. Zool. Stud. 50:475-490

Hundt, P.J., Nakamura, Y. \& Yamaoka, K. 2014. Diet of combtooth blennies (Blenniidae) in Kochi and Okinawa, Japan. Ichthyol. Res. 61:76-82 doi: 10.1007/s10228-013-0366-7

Hyndes, G.A., Platell, M.E., Potter, I.C. \& Lenanton, R.C.J. 1999. Does the composition of the demersal fish assemblages in temperate coastal waters change with depth and undergo consistent seasonal changes? Mar. Biol. 134:335-352. doi: 10.1007/s002 270050551

Hyslop, E.J. 1980. Stomach contents analysis - a review of methods and their application. J. Fish. Biol. 17:411-429 doi: 10.1111/j.1095-864 9.1980.tb02775.x

Jaureguizar, A.J., Menni, R., Guerrero, R. \& Lasta, C. 2004. Environmental factors structuring fish communities of the Río de la Plata estuary. Fish. Res. 66:195-211 doi: 10.1016 /S01657836(03)00200-5

Jones, S.R. 1968. A suggested method for quantifying gut contents in herbivorous fishes. Micronesica. 2:369-371
Kennish, M.J. 2001. Coastal salt marsh systems in the US: a review of anthropogenic impacts. J. Coast. Res. 17:731-748

Kissling, W.D., Rahbek, C. \& Böhning-Gaese, K. 2007. Food plant diversity as broad-scale determinant of avian frugivore richness. Proc. $R$. Soc. B. 274:799-808 doi: 10.1098/rspb.2006. 0311

Kuo, S.R., Lin, H.J. \& Shao, K.T. 2001. Seasonal changes in abundance and composition of the fish assemblage in Chiku Lagoon, southwestern Taiwan. B. Mar. Sci. 68:85-99

Kuo, C.Y., Yuen, Y.S., Meng, P.J., Ho, P.H., Wang, J.T., Liu, P.J,, Chang, Y.C., Dai, C.F., Fan, T.Y., Lin, H.J., Baird, A.H. \& Chen, C.A. .2012. Recurrent disturbances and the degradation of hard coral communities in Taiwan. PLoS ONE. 7:e44364. doi: 10.1371/journal.pone.0044364

Kwun, H.J., Park, J., Kim, H.S., Bae, H. 2016. Preliminary report on fish diversity in the tidal pools of Jeju Island, Korea. Mar. Biodiv. doi: 10.1007/s12526-016-0589-8

Lee, S.C. 1980. Intertidal fishes of a rocky pool of the Sanhsientai, eastern Taiwan. B. I. Zool. Acad. Sinica. 19:19-26

Legendre, P., De Cáceres, M. \& Borcard, D. 2010. Community surveys through space and time: testing the space-time interaction in the absence of replication. Ecology. 91:262-272 doi: 10.1890/09-0199.1

Liu, S.Y.V., Kokita, T. \& Dai, C.F. 2008. Population genetic structure of the neon damselfish (Pomacentrus coelestis) in the northwestern Pacific Ocean. Mar. Biol. 154:745-753. doi: 10.1007/s00227-008-0967-2

Meekan, M.G. \& Choat, J.H. 1997. Latitudinal variation in abundance of herbivorous fishes: a comparison of temperate and tropical reefs. Mar. Biol. 128:373-383 doi: 10.1007/s00227 0050103

Mora, C., Chittaro, P.M., Sale, P.F., Kritzer, J.P. \& Ludsin, S.A. 2003. Patterns and processes in reef fish diversity. Nature. 421:933-936 doi: $10.1038 /$ nature01393

Munday, P.L. 2002. Does habitat availability determine geographical-scale abundances of coral-dwelling fishes? Coral Reefs. 21:105-116 doi: 10.1007/s00338-001-020 0-y

Munoz, A.A., Ojeda, F.P. 1997. Feeding guild structure of a rocky intertidal fish assemblage 
in central Chile. Environ. Biol. Fishes. 49:471479. doi: 10.1023/A:1007305426 073

Murase, A. 2013. Community structure and short temporal stability of a rockpool fish assemblage at Yaku-shima Island, southern Japan, northwestern Pacific. Ichthyol. Res. 60:312326. doi: 10.1007/s10228-013-03 51-1

Murase, A. 2015. Ichthyofaunal diversity and vertical distribution patterns in the rockpools of the southwestern coast of Yaku-shima Island, southern Japan. Check. List. 11:1-21 doi: 10.15560/11.4.1682

Norton, S. \& Cook, A. 1999. Predation by fishes in the intertidal. In: Horn MH, Martin KLM, Chotkowski MA (eds) Intertidal fishes: life in two worlds. Academic Press, San Diego

Novotny, V., Drozd, P., Miller, S.E., Kulfan, M., Janda, M., Basset, Y. \& Weiblen, G.D. 2006. Why are there so many species of herbivorous insects in tropical rainforests? Science. 313:1115-1118. 10.1126/science.1129237

Okada, T., Ishihara, K., Murase, A. \& Hino, T. 2015. A latitudinal gradient in the biogeographic compositions of rock pool fish assemblages on the Pacific coast of central Japan: an examination of the influence of the Kuroshio Current. Biogeography. 17:1-11

Okazaki, D., Yokoo, T., Kanou, K. \& Kohno, H. 2012. Seasonal dynamics of fishes in tidepools on tidal mudflats in the Tama River estuary, central Honshu, Japan. Ichthyol. Res. 59:63-69. 10.1007/s10228-011-0242-2

Pennings, S.C., Ho, C.K., Salgado, C.S., Wieski, K., Davé, N., Kunza, A.E. \& Wason, E.L. 2009. Latitudinal variation in herbivore pressure in Atlantic Coast salt marshes. Ecology. 90:183195 doi: 10.1890/08-0222.1

Plaut, I. 1999. Effects of salinity on survival, osmoregulation, and oxygen consumption in the intertidal blenny, Parablennius sanguinolentus. Copeia. 1999:775-779 doi: $10.2307 / 1447613$

Prochazka, K., Chotkowski, M. \& Buth, D. 1999. Biogeography of rocky intertidal fishes. In: Horn MH, Martin KLM, Chotkowski MA (eds) Intertidal fishes: life in two worlds. Academic Press, San Diego

R Development Core Team. 2016. R: A language and environment for statistical computing. Version
3.2.4. R Foundation for Statistical Computing, Vienna Austria

Shao, K.T., Hsieh, L.Y., Wu, Y.Y. \& Wu, C.Y. 2002. Taxonomic and distributional databases of fishes in Taiwan. Environ. Biol. Fishes. 65:235240 doi: 10.1023/A:102009 2500050

Shao, K.T., 2017. The fish database of Taiwan. WWW Web electronic publication. http://fishdb.sinica.edu.tw

Shieh, S.H. \& Chi, Y.S. 2010. Factors influencing macroinvertebrate assemblages in artificial subtropical ponds of Taiwan. Hydrobiologia 649:317-330 doi: 10.1007/s10750-010-027 $5-\mathrm{y}$

Symonds, M.R.E. \& Moussalli, A. 2011. A brief guide to model selection, multimodel inference and model averaging in behavioural ecology using Akaike's information criterion. Behav. Ecol. Sociobiol. 65:13-21. doi: 10.1007/ s00265010-1037-6

Tsai, C.C., Wong, S.L., Chang, J.S., Hwang, R.L., Dai, C.F., Yu, Y.C., Shyu, Y.T., Sheu, F. \& Lee, T.M. 2004. Macroalgal assemblage structure on a coral reef in Nanwan Bay in southern Taiwan. Bot. Mar. 47:439-453 doi: 10.1515/BOT.2004. 061

Underwood, A.J.. \& Chapman, M.G. 2000. Variation in abundances of intertidal populations: consequences of extremities of environment. Hydrobiologia. 426:25-36. doi: 10.1023/A:10 03995218016

Velasco, E.M., Gómez-Cama, M.C., Hernando, J.A. \& Soriguer, M.C. 2010. Trophic relationships in an intertidal rockpool fish assemblage in the gulf of Cádiz (NE Atlantic). J. Mar. Syst. 80:248-252 doi: 10.1016/j.jmarsys.2009. 10.014

Wen, C.K.C., Chen, K.S., Hsieh, H.J., Hsu, C.M. \& Chen, C.A. 2013. High coral cover and subsequent high fish richness on mature breakwaters in Taiwan. Mar. Pollut. Bull. 72:5563 doi: 10.1016/j.marpolbul. 2013.04.031

Wen, C.K.C., Pratchett, M.S., Shao, K.T., Kan, K.P. \& Chan, B.K.K. 2010. Effects of habitat modification on coastal fish assemblages. $J$. Fish. Biol. 77:1674-1687 doi: 10.1111/j.10958649.2010.02809.x

Wen, K.C., Shao, K.T., Ho, L.T. \& Chen, L.S. 2005. A comparison between clove oil and rotenone for collecting subtropical intertidal fishes. J. Fish. Soc. Taiwan. 32:29-39 
Wilson, S.K. 2000. Trophic status and feeding selectivity of blennies (Blennidae: Salariini). Mar. Biol. 136:431-437. doi: 10.1007 /s002 270050702

Wilson, S.K., Burns, K. \& Codi, S. 2001. Sources of dietary lipids in the coral reef blenny Salarias patzneri. Mar. Ecol. Prog. Ser. 222:291-296 doi: 10.3354/meps222291

Wilson, S.K., Bellwood, D.R., Choat, J.H. \& Furnas, M.J. 2003. Detritus in the epilithic algal matrix and its use by coral reef fishes. In: Gibson RN, Atkinson RJA (eds) Oceanography and marine biology: an annual review, volume 41. Taylor and Francis, London

Work, T.T., Jacobs, J.M., Spence, J.R. \& Volney, W.J. 2010. High levels of green-tree retention are required to preserve ground beetle biodiversity in boreal mixedwood forests. Ecol. Appl. 20: 741-751 doi: 10.1890/08-1463.1

Worm, B., Sandow, M., Oschlies, A., Lotze, H.K. \& Myers, R.A. 2005. Global patterns of predator diversity in the open oceans. Science 309: 1365-1369 doi: 10.1126/science.1113399

Yoshiyama, R.M., Sassaman, C. \& Lea, R.N. 1986. Rocky intertidal fish communities of California: temporal and spatial variation. Environ. Biol. Fishes. 17:23-40 doi: 10.1007 /BF00000398

Ysebaert, T. \& Herman, P.M.J. 2002. Spatial and temporal variation in benthic macrofauna and relationships with environmental variables in an estuarine, intertidal soft-sediment environment. Mar. Ecol. Prog. Ser. 244:105-124. doi: 10.3354/meps244105

Zabin, C.J., Danner, E.M., Baumgartner, E.P., Spafford, D., Miller, K.A. \& Pearse, J.S. 2013. A comparison of intertidal species richness and composition between Central California and Oahu, Hawaii. Mar. Ecol. 34:131-156 doi: 10.1111/maec.12007 